Pure Sciences

Oral

Abstract ID: 147

\title{
Extraction optimization and properties of collagen from chicken (Gallus gallus domesticus) feet
}

Nur Dhiya Mokhtar ${ }^{\mathrm{a}}$ | Widya Abdul Wahab ${ }^{\mathrm{a}}$ | Hazrina Ab. Hadi ${ }^{\mathrm{b}}$ | Muhamad Shafiq Abu Hassan ${ }^{\mathrm{a}}$ | Normah Haron ${ }^{\mathrm{a}}$ | Noraslinda Muhamad Bunnori ${ }^{\mathrm{a}}$

${ }^{a}$ Kulliyyah of Science, International Islamic University Malaysia

${ }^{b}$ Kulliyyah of Pharmacy, International Islamic University Malaysia

Introduction: The collagen can be basically extracted by chemical and enzymatic hydrolysis. In industry, the chemical hydrolysis method is more commonly used. However, the enzymatic hydrolysis is more effective when the high nutritional value product will be produces based on the extracted material. Chicken (Gallus gallus domesticus) feet are used as a source of bird collagen. Methods: Optimization of collagen extraction was investigated by using three different methods which were soaked in $5 \%$ lactic acid for 36 hours, $0.5 \mathrm{~mol} / \mathrm{L}$ acetic acid with $0.1 \%$ papain and $0.5 \mathrm{~mol} / \mathrm{L}$ acetic acid with $0.1 \%$ bromelain. Various properties such as percentage of end yield, concentration of protein, $\mathrm{pH}$, swelling percentage and SDS-PAGE patterns of collagen from chicken feet were evaluated in order to determine the best method of extraction. Results: Type I collagen was considered as a major component of chicken feet collagen, which indicated by $B$ chain and two distinct a-chains which are a1 and a2 that observed from the electrophoresis pattern of collagen extracted from all three methods. The lactic acid method showed the highest percentage of end yield and concentration of protein compared to the other two methods. However, lactic acid method showed the lowest swelling percentage and higher $\mathrm{pH}$ value. Conclusions: According to these results, soaked in 5\% lactic acid for 36 hours is possible as the best collagen extraction method from chicken feet.

KEYWORDS: Chicken feet, collagen, lactic acid, papain, bromelain 